\title{
Basic Word Order in Tombulu Language ${ }^{1}$
}

Darsita. S

\begin{abstract}
Abstrak
Artikel ini menganalisis konstruksi tata urutan kata dalam kalimat bahasa Tombulu, yang dituturkan oleh para penutur jati bahasa Tombulu yang bermukim di Kecamatan Tombulu Kabupaten Minahasa. Kalimat dalam konteks kajian ini dipahami sebagai satuan bahasa yang berisi suatu "pikiran" atau "amanat" yang lengkap. Lengkap, berarti di dalam satuan bahasa atau kalimat itu terdapat beberapa bagian yaitu: 1) bagian yang menjadi pokok pembicaraan, yang lazim disebut dengan istilah subjek (S), dan yang biasa menjadi subjek adalah kata benda; 2) bagian yang menjadi "komentar" tentang subjek, yang lazim disebut dengan istiah predikat, dan yang biasa menjadi predikat adalah kata kerja atau verba (V); 3) bagian yang menjadi pelengkap dari predikat yang lazim disebut objek (O), dan yang biasa menjadi objek adalah kata benda. Kalimat tunggal dalam bahasa Tombulu dilihat melalui tataran sintaksis yakni ilmu tentang tata bahasa yang menelaah hubungan kata-kata dalam kalimat, dan cara-cara menyusun kata-kata itu untuk membentuk kalimat. Hasil analisis terhadap kalimat tunggal diketahui bahwa bentuk kalimat itu dalam bahasa Tombulu memiliki tiga tipe urutan kata, yaitu urutan kata yang berupa SVO; SV; VS; dan VSO.
\end{abstract}

Kata Kunci: Bahasa Tombulu, urutan kata, kalimat tunggal, subjek, verba dan objek

\section{Introduction}

Basic word order. As Nora (2007: 446) demonstrates, the definition of basic word order is quite problematic. Different criteria are used by different linguists, languages differ greatly in the ease with which a basic word order can be established, and there has been relatively little discussion of the assumptions that underlie the idea of basic word order. Broady (1984: 54) lists criteria that have been suggested for establishing basic word order under the general categories of simplicity, least markedness, reciprocally affecting verb, disambiguation, full nouns for nominal constituents, and frequency. Based on the word order problematic, I hold about basic word order before discussing further the situation in Tombulu.

1 The research for this present paper carried out in 2008 in Tombulu subdistrict Main Minahasa (Minahasa Induk) North Sulawesi Indonesia where I had the grand good fortune to be able to observe this language in a sociolinguistics team. I owe a great debt to the team of the STAIN Manado's observers and native speakers of Tombulu with whom I was able to discuss many details of the grammars of Tombulu language. They, more any others, stimulated my thinking about detail of word order and brought me to recognize the joys of basic word order of syntax and comparative linguistics. 
The "major constituents" that are usually considered for the establishment of basic word order are the verb and its subject and object, used here in a standard or traditional sense. There are the arguments that are usually in a direct relationship to a transitive verb. They are also the arguments that, at least in some languages under certain relatively rarely occurring circumstances, may need to be distinguished by some syntactic means for utterance to be intelligible. That is, if a language has no case marking to differentiate the syntactic roles of the major constituents, a sentence with explicit nouns for subjects and object which can reciprocally affect each other or to be understood as either subject or object requires some mechanism for indicating the syntactic role for each. Word order may provide that mechanism.

Thus, the idea of basic word order is fundamentally syntactic. In trying to make sense out of the various criteria offered as characteristic of basic word order, it seems to me that the syntactic criteria must be considered first, always keeping in mind that the point of ordering subject and objects with respect to the verb is at least in part to help keep them straight when other more usual mechanisms such as or discourse strategies fail. Therefore, the criteria that I consider in the establishment of basic word order are (in order): 1) syntactic criteria, 2) non syntactic criteria that have demonstrated affects on syntax, especially order, and 3) other considerations that affect the analysis.

1) Syntactic criteria

(1) The sentence must have a transitive verb and a subject and object both expressed as nouns. Basic word order is generally taken to refer to the order found for the three constituent of verb, subject, object (in their usual or traditional senses). While ordering principles in sentences without one of the nominal constituents or with intransitive verbs and subjects may also be interesting or illuminating with regard to order phenomena, it is only the sentence with a transitive verb and both subjects and object that contains simultaneously the constituents necessary for establishing basic word order. $^{2}$ In fact in Tombulu language where the independent pronouns seem to be more truly "independent" and therefore

${ }^{2}$ If a language were found to have different basic verb-subject orders for transitive and intransitive subjects, then basic word order would have to be based on an analysis of both transitive and intransitive clauses. This would of course also call into doubt the idea of undifferentiated "subject" as a basic category, at least in the language that showed such variation. Tombulu language does not, as far as I am aware, has different basic word orders that depend on the distinction between transitive and intransitive subjects, although they differentiate them considerably in pragmatic terms. 
reasonable candidates for lexical manifestations of subjects or objects, it may be the case that there are order restrictions in their use or that they are somewhat more focusing that lexical noun. This first point is the single necessary criterion for basic word order. Points 2-8 are further guides to where to look for basic word order but are not absolute criteria the issue of where unmarked or neutral orders are most likely to be found.

(2) In Tombulu language, the sentence is simple rather than complex (or at least the clause is a main clause). Subordinate clauses may be more restricted in word order possibilities than main clauses Steele (1978: 33) or may involve obligatory rearrangements. This is true of Tombulu language. For instance, many can be analyzed as having some sort of fronting rule that operates in the construction of relative clauses. The presence of such a rule may be manifested in a number of different ways: by the use of a relative pronouns showing some sort of extraction, by the use of movement particles or subordinate aspect markers on the verb that show rearrangements, or by the obligatory use of the focus anti passive when the relative nouns is a transitive subject, showing that it has been extracted. ${ }^{3}$

(3) The verb must be indicative, affirmative, and active. Changes in mood may involve obligatory rearrangements of order, as may negatives and interrogatives. Changes in voice usually affect valence, resulting in sentences that no longer fulfill the first criterion because the verb is no longer transitive. They may additionally involve obligatory changes in order.

(4) The sentence should have an interchangeable subject and object (Durbin and Ojeda, 2008:448). If the subject can be understood to be the object and vice versa, then word order is called on maximally to distinguish between subject and object. Tombulu language have no overt case marking on the nouns themselves, so the sort of sentence in which the subject and object are interchangeable does in fact rely on word order for distinguishing subjects from objects.

(5) Sentences should not be ambiguous in interpretation of subject and object (Durbin and Ojeda, 2008: 449).

${ }^{3}$ Other languages do not necessarily work this way, so there may be reason to look to subordinate clauses for basic word order. Analysis of the characteristics for both main and subordinate clauses must be done for each language in order to know where to find basic word orders, so I am not suggesting that subordinate clauses are unimportant in analysis of word order, only that in Tombulu they are likely to have rearranged word orders. 
(6) No constituent is focused, topicalized, or otherwise highlighted. Focus, topicalized, and highlighting often result in rearrangements and other pertinent syntactic changes. Tombulu language typically require that such constituents be first in the sentence. Most of them furthermore require the use of the focus antipassive (Nora, 2007: 449) if the focused topicalized, or highlighted constituent is the transitive subject, thus changing the valency of the verb.

(7) In Tombulu the subject noun is definite. If there are different possible orders according to definiteness of the nominal constituent, the most neutral (and hence basic) is that in which the subject is definite. According to Dubois (1987: 3), there is a universal discourse constraint against introducing new information as the transitive subject, while there is no such constraint against introducing new information as the object. Definiteness marks, among other things, old information. Thus transitive subjects are typically not indefinite, while transitive objects may be.

(8) In Tombulu, the subject noun is animate. If there are different possible orders according to an animacy hierarchy, the most neutral ( and hence basic) is that in which the subject is animate. Most active transitive subjects can be expected to be agents and therefore animate. Objects are most often patients and can be either animate or inanimate. While semantically most neutral sentence might have an animate subject and inanimate object (or at least that is lower in an animacy hierarchy that the subject), the syntactic requirement that the subject and object be capable of being interchanged suggests that basic word order sentences will have both animate subject and animate objects.

\section{Word Order in Tombulu Language}

\subsection{Tombulu Data}

Tombulu language is usually analyzed as subject-initial. Tombulu language is characterized by the present of SVO sentence and by the fact that orders other than SVO normally require further grammatical changes. In this language, for instance, it is possible to place the $\mathrm{S}$ or $\mathrm{O}$ in front of the verb (for emphasis), but then the classifier associated with the moved constituent appears in its original position, thus preserving word order.

(1a) Base sentence: 


\begin{tabular}{|l|l|l|l|l|l|l|l|}
\hline Nyaku & Mahwitu-witu & wade & ti’ $i$ & 'Saya & tinggal & di rumah & itu' \\
\hline S & $\mathrm{V}$ & $\mathrm{O}$ & & & & & \\
\hline 'saya' & 'tinggal' & 'rumah' & 'itu' & & & & \\
\hline
\end{tabular}

(1b) Base sentence

\begin{tabular}{|l|l|l|l|l|l|l|l|}
\hline Ama & matu meles & kan wo & Sera & 'Ayah & membeli & nasi dan & ikan' \\
\hline $\mathrm{S}$ & $\mathrm{V}$ & $\mathrm{O}$ & & & & & \\
\hline 'ayah' & 'membeli' & 'nasi dan' & 'ikan' & & & & \\
\hline
\end{tabular}

(1c) Base Sentece

\begin{tabular}{|c|c|c|c|c|c|c|c|}
\hline Sendee & weneheano & nasi ni & ina & 'Sayur & sedang & digarami & oleh ibu' \\
\hline $\mathrm{S}$ & V & $\mathrm{O}$ & & & & & \\
\hline 'sayur' & 'digarami' & 'sedang' & 'ibu' & & & & \\
\hline
\end{tabular}

* SVO is my interpretation

(1d) Fronted subject

\begin{tabular}{|l|l|l|l|l|}
\hline Kapotok & tou & 'Orang & itu & pendek' \\
\hline V & S & & & \\
\hline 'pendek' & 'orang' & & & \\
\hline
\end{tabular}

*VS is my interpretation

(1e) Fronted subject

\begin{tabular}{|l|l|l|l|l|}
\hline Mahapus & kai kooki tuari ni ina & 'Paman & Sedang mengikat & kayu api' \\
\hline $\mathrm{V}$ & $\mathrm{S}$ & & & \\
\hline
\end{tabular}




\begin{tabular}{|l|l|l|l|l|}
\hline 'mengikat kayu' & 'paman' & & \\
\hline
\end{tabular}

*VS is My interpretation

\begin{tabular}{|l|l|l|l|l|}
\hline Re'kan ti'i & Ambarang penerengko & 'bukan & barang itu & yang saya butuhkan ' \\
\hline $\mathrm{V}$ & $\mathrm{S}$ & & & \\
\hline 'butuh itu' & 'bukan barang saya' & & & \\
\hline
\end{tabular}

*VS is my interpretation

(1g) Fronted Subject

\begin{tabular}{|l|l|l|l|l|}
\hline Meyeh & wehan towa & 'orang itu & datang & kemarin' \\
\hline V & S & & & \\
\hline 'datang' & 'orang itu kemarin' & & & \\
\hline
\end{tabular}

*VS is my interpretation

Let us begin by looking at Tombulu. It has been subject of more word order research than any other Minahasa language, with fairly comprehensive statements by Salea (1978). In this paper I used the following elicitation frame to investigate subject-initial order in Tombulu. A sentence with interchangeable nouns and appropriate verb was elicited. Because of the context translation and elicitation, in which it seems to be the case that speakers minimally topicalize the subject noun in order to provide some context for sentences solicited in isolation, such sentences were without exception rendered by Tombulu speakers first in SVO order. Than I recorded the constituents so as to produce verb-initial versions and asked for acceptability judgment and interpretations of the sentences thus produces. I also changed the definiteness value of the subjects and objects. All sentences were constructed orally; I wrote them down at the same time and the Tombulu speakers (fully literate in Tombulu) were able to read them as well as listen to them. 
(2a) SV rendition, definite human S and V

\begin{tabular}{|l|l|l|l|l|l|l|l|l|}
\hline Walle & dempar ti'iti & timeless $k u$ & Mah & 'rumah lebar & itu & sudah & saya & beli' \\
\hline S & V & S & V & & & & & \\
\hline 'rumah' & lebar 'itu' & 'saya' & 'beli' & & & & & \\
\hline
\end{tabular}

*SV SV is my interpretation

(2b) SV rendition, definite human S and V

\begin{tabular}{|l|l|l|l|l|l|l|l|}
\hline Nihu & kondeng ti'iti & sera & wu'as & 'nyiru kotor & itu & mereka & cuci' \\
\hline S & V & S & V & & & & \\
\hline 'nyiru' & kotor itu' & 'mereka' & 'cuci' & & & & \\
\hline
\end{tabular}

*SV SV is my interpretation

(2c) First V-initial reordering:

\begin{tabular}{|l|l|l|l|l|l|l|l|}
\hline Soomange & \multicolumn{1}{|c|}{ sia } & ma'ayang & 'dia & sudah & tidak & mau & bekerja' \\
\hline V & S & O & & & & & \\
\hline 'sudah' & dia' & 'tidak mau kerja' & & & & & \\
\hline
\end{tabular}

(2d) First V-initial reordering

Wiamo tuawitu sekolah

‘Kepala sekolah kami sudah datang’

V S O

'sudah datang' 'kepala sekolah' 'kami'

\begin{tabular}{|l|l|l|l|l|l|l|l|}
\hline Wiamo & tuawitu & sekolah & 'pimpinan & sekolah & kami & sudah & datang' \\
\hline
\end{tabular}




\begin{tabular}{|l|l|l|l|l|l|l|l|}
\hline V & S & O & & & & & \\
\hline $\begin{array}{c}\text { 'sudah } \\
\text { datang }\end{array}$ & 'pimpinan' & 'sekolah' & & & & & \\
\hline
\end{tabular}

*VSO is my interpretation base on native speakers talk orally

(2e) First V-initial reordering

\begin{tabular}{|l|l|l|l|l|l|}
\hline Wahu & karai ti'iti & sera & 'Baju & mereka & basah' \\
\hline V & S & O & & & \\
\hline 'basah' & baju' & 'mereka' & & & \\
\hline
\end{tabular}

*VSO is my interpretation

The sentences above have SVO or VSO order

(3a) A sentence with indefinite -ange -um

Weritange um peda witi'i 'singkirkan saja golok itu'

$\mathrm{V} \quad \mathrm{S}$

Pengkange um watu kasedah witi'i 'belahkan batu besar itu

V

S

\begin{tabular}{|l|l|l|l|l|}
\hline Weritange & um peda witi'i & 'Singkirkan & saja & golok itu' \\
\hline V & S & & & \\
\hline 'singkirkan' & golok' & & & \\
\hline
\end{tabular}

*VS My interpretation

\begin{tabular}{|l|l|l|l|l|l|}
\hline Pengkange & Um & sera & 'Baju & mereka & basah' \\
\hline $\mathrm{V}$ & $\mathrm{S}$ & $\mathrm{O}$ & & & \\
\hline
\end{tabular}




\begin{tabular}{|l|l|l|l|l|l|}
\hline 'basah' & baju' & 'mereka' & & & \\
\hline
\end{tabular}

(3b) A sentence with indefinite -ke

\begin{tabular}{|l|l|l|l|l|l|}
\hline Mawongke & mahoro & 'Mereka & Baru & saja & bangun' \\
\hline V & S & & & & \\
\hline 'bangun' & 'mereka' & & & & \\
\hline
\end{tabular}

(3b) A Sentence with indefinite $-k e$

\begin{tabular}{|l|l|l|l|l|l|}
\hline Matampangke & Oki ni'doka & Anak ayam & 'Jantan itu & sedang & berjalan' \\
\hline V & S & & & & \\
\hline 'berjalan' & anak ayam jantan' & & & & \\
\hline
\end{tabular}

The same ordering principles apply if the object is inanimate. Here the semantics make it clear that -ange is embedded to the verb and -ke is embedded to the subject. In summary, Tombulu is analyzed by most linguist as a SVO language. SVO, a very common order, results from processes of topicalization or focus. VSO is possible and apparently not uncommon order in text, it is common orally. My elicited data suggest that the object need not be complex and that VSO is also preferred order when both the subject and object is indefinite 'unmarkerd'.

\section{Analysis}

Having examining data in more detail, I conclude that Tombulu has SVO order. The original distinction I drew, that there are VSO order is not useful. This language fall on a continuum from accepting VSO rather readily under some conditions, to accepting it only under very restricted circumstances, to not accepting it at all. 
Tombulu can be characterized as being rigidly SVO order. Other orders are pragmatically and usually grammatically marked. In my opinion, SVO can be analyzed in most cases as a focus or topicalization order and thus is a good candidate for basic word order. Tombulu word order can be further divided into two major groups: those that permit SVO and VSO word order. It enable us us to explain, Norman and Campbell (2009: 226) points out, how both SVO and VSO word order language could develop from a common source. Based on my Tombulu data language, this language commit us to accept that they were both basic. The complex object condition results in a reordering rule: if the object is complex, move it to the end of the sentence. Perhaps the animacy condition and the definiteness condition can be treated in a similar way. In the criteria for basic word order I suggest that the animacy and definiteness of the subject noun are important(1a-1c). Subject nouns are expected to be agents and therefore are likely to be definite. Hence basic word order sentences will have animate and definite subject nouns. No such expectations regarding object exist. They are usually patients, which can be animate or inanimate, and they can be old and new information, so either definite or indefinite. The following possibility types all qualify as basic word order sentences:

\begin{tabular}{|l|l|}
\hline Subject Noun & Object Noun \\
\hline+ animate & + animate \\
\hline+ definite & +definite \\
\hline & \\
\hline +animate & +animate \\
\hline+ definite & -definite \\
\hline & \\
\hline +animate & -animate \\
\hline -definite & +definite \\
\hline
\end{tabular}

What Tombulu language that has both SVO and VSO or VS, or SV seem to do is reserve VSO for those instances in which the object noun is positively marked for either animacy or definiteness, while VSO is used when the object is neither animate or definite. Therefore, VSO is used when the $\mathrm{S}$ is higher than the $\mathrm{O}$ in one of these features, since the nouns are always animate and definite. If we consider that the complex object condition is a rule that states that VSO is used when the object is positively marked. We could similarly 
consider that positive marking for animacy or definiteness can also result in reordering. This would assume a basic word order of SVO in all instances with VSO resulting from application of one of three forms of a reordering rule. It suggests a language-family-specific criterion for basic word order: basic word order sentences have object that are unmarked for complexity, animacy, or definiteness. Is there any motivation for doing this? The motivation for considering the complex object condition a recording rule is fairly obvious: complex objects may be more difficult to process than simple objects, especially when they are situate between verb and the subject begins. There is equally obvious pragmatic reason for a reordering rule to be necessary for animacy and definiteness. Based on my observation, if I accept that topic and focus positions are preverbal, that there is a sentence-final "reordering" position that is filled by complex, animate, or definite objects, then the structure of Tombulu sentence is:

\section{TOPIC FOCUS [S V O] REORDERED $\mathrm{O}$}

All possible orders can be derived from this, and since a number of Tombulu language data shows me all possible orders, this is important:

\begin{tabular}{|l|l|}
\hline Order & Derivation \\
\hline SVO & SVO \\
\hline VSO & {$\left[\mathrm{S} \_\right.$V] REORDERED O } \\
\hline SVO & TOPIC FOCUS [VO_] \\
\hline
\end{tabular}

Accepting for the moment that this is possible characterization of Tombulu, let me say, an analysis that would proposed VSO as the basic word order for Tombulu with derivations that gives VSO does not make sense, for various reasons. Presumably, some ordering rule would still be necessary to produce VSO, but there is no motivation for moving the $\mathrm{S}$ to the end of the sentence. The current SVO language is very clear about order; almost all change orders are grammatically marked, there is almost no ambiguity and few restrictions on types of constituents that can fill the subject or object positions. In may be the case that, in Tombulu language in particular, a grammatical restriction against indefinite subjects noun phrases (NPs) exists or is developing. This would presumably be a grammaticalization of the discourse, that agents are typically used to convey new information. 


\section{Conclusions}

This analysis shown that Tombulu language differ considerably in order word phenomena in Proto Malay language. Based on previous analyses of Tombulu word order have concluded that Tombulu word order was certainly subject-initial, was probably SVO, and may have been mixed VSO. I suggest that Tombulu was SVO and that the structure of the sentence includes two preverbal position for TOPIC and FOCUS. Thus the structure can be diagrammed as follows:

\section{TOPIC FOCUS [SVO] REORDERED O}

This structure has the advantages of treating marked objects the same and providing derivations for all the orders that are found in Tombulu languages that seems to fit fairly well with the conditions under which those orders occur. This language that promoted the $\left\{\left[\mathrm{S}_{-} \mathrm{V}\right]\right.$ REORDERED $\left.\mathrm{O}\right\}$ derivation at the expense of VOS have clear, stable word order. What has only been touched on briefly here are that functions of various word orders that are encountered in the different Minahasa languages. Although, I have defined "basic word order" for Tombulu language as an essentially syntactic category, the factors that condition the use of different word orders area not only, or not even principally, syntactic. Arriving at an understanding of the syntax of word order paves the way for analyzing the interaction of those factors - syntactic, pragmatic, discourse- based - that ultimately affect word order choice. 


\section{REFERENCES}

Bickford, J Albert. 1991. A Course in Basic Grammatical Analysis. Tucson USA: Summer Institute of Linguistics, Press.

Bloomfield, Leonard. 1993. Language. New York: Holt Rinehart and Winston

Brody, Jill. 1984. "Some problems with the concept of basic word order". In International Jorunal of American Linguistics, Vol 57, No 4 (October., 1991), pp 446-486.

Brown, E.K. dan J.E. Miller. 2009. Syntax: Generative Grammar. London: Hutchinson

Chomsky, Noam. 1965. Aspect of the Theory of Syntax. Massachusetts: The M.I.T Press 1972. Language and Mind. New York: Harcout Brace Jovanovich

Danie, Julius Akun. 1991. Kajian Geografi Dialek Minahasa Timur Laut. Jakarta: SERI ILDEP di bawah redaksi W.A.L Stokof, Balai Pustaka.

1991. Bahasa dan Dialek di Kecamatan Kakas dan Sekitarnya. Jakarta: Departemen P dan K. Proyek Bahasa dan Sastra Indonesia dan Daerah.

Djajasudarma, Fatimah. 1993. Metode Linguistik Ancangan Metode Penelitian dan Kajian. Bandung: Eresco.

Kridalaksana, Harimurti. 1984. Tata Bahasa Deskriptif Bahasa Indonesia, Sintaksis. Jakarta: Pusat Pembinaan dan Pengembangan Bahasa.

Masinambow, EKM dan Paul Haenan. 2003. Bahasa Indonesia dan Bahasa Daerah. Jakarta: Yayasan Obor Indonesia

Nora, C England. 2007. "Changes in Basic Word Order in Mayan Languages". In International Journal of American Linguistics, Vol 57, No 4 )Oct., 1991), pp 446-486.

Mithun, Marriane. 1987. " Is Basic Word Order Universal? Coherence and Grounding in Discourse”. In Typoclogical Studies in Language. Vol 11, pp. 281-328. Amsterdam: John Benjamins.

Ramlan, M. 1981. Ilmu Bahasa Indonesia, Sintaksis. Yogyakarta: UP Karyono

Salea, W. Martha. 1980. Kamus Tombulu Indonesia. Jakarta: Departemen P dan K Proyek Bahasa dan Sastra Indonesia dan Daerah.

Steele, Susan. 1978. "Word order variation: a typological study". In Universals of Human Language, ed. Joseph H. Greenberg, Vol 4, Syntax, pp 585-624. Stanford, Calif: Stanford University Press

Stockwell, Robert P. 1977. Foundations of Syntactic Theory. New Jersey: Prentice Hall

Thomson, Sandra A. 2008. "Modern English from a typological points of view: some implications of the function of word order". Linguistische Berichte Vol 54, No 1 (January, 2008), pp 19-35.

Warokka, Djery H. 2005. Kamus Bahasa Daerah Manado-Indonesia. (Indonesia-ManadoTountemboan-Toulour-Tonsea-Tombulu). Jakarta: Alfa Indah 
Jurnal Iqra' Vol.5. No.1, Januari - Juni 2011

Wray, Alison and Kate Trott. 1988. Projects in Linguistics A Practical Guide to Researching Language. London: Arnold 